\title{
Forensic Identification of Decomposed Human Body through Comparison between Ante-Mortem and Post-Mortem CT Images of Frontal Sinuses: Case Report
}

\footnotetext{
${ }^{1}$ Stomatološki fakultet - Zavod za forenzičku stomatologiju Federalnog sveučilišta, Goias, Brazil Forensic Dentistry, Federal University of Goias, Brazil

2 Stomatološki fakultet - Zavod za maksilofacijalnu radiologiju Federalnog sveučilišta Goias, Brazil Maxillofacial Radiology, Federal University of Goias, Brazil

${ }^{3}$ Brazilska stomatološka udruga - Ogranak za maksilofacijalnu radiologiju

Maxillofacial Radiology, Brazilian Dental Association - State of Goias, Brazil

${ }^{4}$ Stomatološki fakultet - Zavod za forenzičku stomatologiju Katoličkog sveučilišta, Leuven, Belgija

Forensic Dentistry, Katholieke Universiteit Leuven, Belgium

${ }^{5}$ Forenzička antropologija Policijske akademije, Goias, Brazil

Forensic Anthropology, Scientific Police of Goias, Brazil
}

\section{Sažetak}

Svrha: Izvijestiti o slučaju pozitivne identifikacije raspadnutog tijela nakon usporedbe prijesmrtnih (ante mortem - AM) i poslijesmtrnih (post mortem - PM) prikaza kompjutorizirane tomografije frontalnih sinusa. Prikaz slučaja: Nepoznato tijelo u visokom stupnju raspadanja, u dobi od 30 do 40 godina, pronađeno je u šumskom području Brazila. Dentalnom autopsijom otkrivena je djelomična proteza te da je neidentificirana osoba ostala bez nekoliko zuba još prije smrti. Potraga za podatcima o prijesmrtnom statusu rezultirala je slijedom od 20 aksijalnih slika paranazalnih sinusa dobivenih kompjutoriziranom tomografijom (MSCT). Provedeno je poslijesmrtno MSCT slikanje kako bi se usporedbom omogućila identifikacija. Neposredna usporedba prijesmrtnih i poslijesmrtnih MSCT podataka pokazala je morfološka poklapanja, posebno za lateralnu ekspanziju lijevog kraka, anteroposteriornu dimenziju i položaj medijalnog i dodatnih septa sinusa. Zaključak: U ovom tekstu istaknuto je koliko je važno čuvati medicinske podatke radi interpretacije radiografskih podataka i njihove primjene u pravosuđu.
Zaprimljen: 1. prosinca 2016. Prihvaćen: 12. veljače 2017.

Adresa za dopisivanje Rhonan Ferreira Silva Federal University of Goias Av. Universitaria, Esquina com $1^{\text {a }}$ Avenida $\mathrm{s} / \mathrm{n}$, Setor Universitario 74605-220 Goiania, Goias, Brazil tel: 00556232096051 rhonanfs@terra.com.br

Ključne riječi forenzička antropolgija; humana identifikacija; frontalni sinus; računalna tomografija rendgenskim zrakama; označavanje zubne proteze

\section{Uvod}

Forenzička radiologija grana je forenzičke znanosti u razvoju i ima posebno značenje kad je riječ o odgovaranju na pravna pitanja u vezi sa smrću (1) i identifikacijom nepoznatih žrtava (2). Općenito, identifikacija ljudi postupkom radiografskih dokaza sastoji se od usporedbe prijesmrtnih (AM) i poslijesmtrnih (PM) podataka (3) koji su zabilježeni uglavnom na konvencionalnim zubnim i maksilofacijalnim radiogramima (4). Posljednjih je godina tomografija (CT) postala uobičajena u medicinskoj praksi i prevladava kad su potrebni prijesmrtni podatci (5). U opisanom slučaju radi se o pozitiv-

\section{Introduction}

Forensic radiology as an emerging branch of forensic sciences plays a valuable role by providing answers about deceased individuals in court procedures, particularly those related to the cause of death (1) and identification of unknown victims (2). In general, it provides solid ante mortem (AM) radiographic evidence for comparison with postmortem findings in human identifications (3) which are registered mainly through conventional dental and maxillofacial radiographs (4). However, in the last few years, computed tomography (CT) has become popular in medical routines and has been 
noj identifikaciji ljudskog tijela u visokom stupnju raspadanja nakon usporedbe prijesmrtnih i poslijesmrtnih forenzičkih dokaza zabilježenih na CD slikama frontalnih sinusa.

\section{Prikaz slučaja}

Godine 2013. pronađeni su ljudski ostatci u visokom stupnju raspadanja u šumskom području Brazila. Nakon završenog očevida truplo je preneseno u ovlašteni lokalni medicinsko-patološki institut. Antropometrijskom analizom ustanovljeno je da je riječ o ženskoj osobi u dobi od 30 do 40 godina $(6,7)$ i visokoj između 158 i 166 centimetara (8). Autopsijom zuba otkrivena je djelomična mobilna proteza, a nekoliko zuba bilo je izvađeno prije smrti.

Policajci su tijekom istrage otkrili i tko je potencijalna žrtva - 33-godišnja žena koja je bila nestala prije sedam dana. Od njezine rodbine zatražen je bilo kakav prijesmrtni medicinski ili zubni podatak kako bi se, radi napretka istrage, omogućila komparativna identifikacija ljudskih ostataka. To je rezultiralo s 20 aksijalnih snimaka paranazalnih sinusa dobivenih multi slice kompjutoriziranom tomografijom (MSCT) iz 2012. (slika 1.). Na trima snimkama jasno se vidjela anteroposteriorna i lateralna dimenzija frontalnih sinusa, uključujući i njegove režnjeve i pregrade (medijane i dodatne). Nakon toga zatraženi su kompletni DICOM podatci, ali bez uspjeha jer u mjesnoj bolnici nisu pronađene arhivirane MSCT slike.

Sličnost između antropološkog profila žrtve i nestale osobe potaknula je preliminarnu analizu poslijesmrtnoga frontalnog sinusa koristeći se postanterionalnom radiološkom slikom lubanje (slika 2.). Pronađeni su frontalni sinusi malih dimenzija i središnji septum pomaknut na desnu stranu te lijevi lobul $s$ većim bočnim proširenjem u usporedbi s nasuprotnim. Nakon toga slijedio je poslijesmrtni pregled s pomoću kompjutorizirane tomografije koničnom zrakom (CBCT) uređajem CB500 Gendex (KaVo Kerr Group', Njemačka), što je omogućilo prijesmrtnu i poslijesmrtnu usporedbu CT podataka (slika 3.). Za pronalazak najboljih poslijesmrtnih presjeka frontalnih sinusa za usporedbu s prijesmrtnima, korišten je preglednik DICOM-a (Osirix (PixmeoSarl', Švicarska). U neposrednoj usporedbi prijesmrtnih i poslijesmrtnih podataka podudarali su se morfološki nalazi frontalnih sinusa žrtve i nestale osobe. Točnije, pronađena je sukladnost u bočnom širenju lijevoga režnja i anteroposteriornoj dimenziji, te u smještaju središnje i akcesornih koštanih pregrada. $\mathrm{Na}$ osnovi tih dokaza pronađeni ljudski ostatci pozitivno su identificirani.

\section{Rasprava}

Sve više zahtjeva za CT preglede potaknulo je prilagodbu u usporedbi prijesmrtnih i poslijesmrtnih podataka koja je, od uspoređivanja konvencionalnih radiograma, došla do tehnološki naprednijih oblika. Od ove promjene najviše je koristi imao postupak identifikacije ljudi jer se postigla pouzdanija i realnija usporedba forenzičkih podataka $(3$, most frequently used method for providing AM data in the forensic routine (5). The present study reports on a case of positive human identification of a heavily decomposed human body. A comparison was made between AM and PM forensic evidence registered from $\mathrm{CT}$ images of frontal sinuses.

\section{Case report}

In 2013, heavily decomposed human remains were found in a forest region in Brazil. After the crime scene investigation, the remains were referred for forensic exams at the local medico-legal institute. The anthropological analysis pointed to a female victim aged between 30 and 40 years $(6,7)$, with height ranging from $158 \mathrm{~mm}$ to $166 \mathrm{~mm}(8)$. The dental autopsy revealed the presence of removable partial prostheses and several AM missing teeth.

In parallel, Police acknowledged they believed that a 33-year-old woman who went missing for seven days was the victim of a crime. The relatives of the missing person were asked to provide any AM medical or dental records to support the evidence and enable a comparative human identification. The search resulted in a sequence of 20 axial images of the paranasal sinuses obtained by Multislice Computed Tomography (MSCT) dating from 2012 (Figure 1). Three images showed clearly the anteroposterior and lateral dimensions of the frontal sinuses, including its lobes and septa (median and accessory). Complete DICOM files were requested resulting unsuccessfully because no record of the MSCT exam was found archived at the local hospital.

The similarity between the anthropological profile of the victim and the missing person led to the PM preliminary analysis of the frontal sinuses using a posteroanterior radiograph of the skull (Figure 2). Bilateral frontal sinuses of small dimensions were observed, as well as a median septum dislocated to the right side and a left lobe with larger lateral expansion compared to the contralateral. Afterwards, a PM conebeam computed tomography (CBCT) exam was performed using a CB500 Gendex (KaVo Kerr Group', Germany) unit enabling the AM/PM CT data comparison (Figure 3). In Osirix (Pixmeo Sarl', Switzerland) DICOM viewer, the PM slices that reproduced the best AM images of the frontal sinuses were searched.

The direct comparison between AM/PM CT data was made and morphological findings of the frontal sinuses of the victim were shown to be consistent with those belonging to the missing person. Specifically, the compatibility between data was found on the lateral expansion of the left lobe, the anteroposterior dimension, and the position of median and accessory septa. An evidence-based positive identification of human remains was established.

\section{Discussion}

The increasing demand for CT exams in the routine of medical services triggers a modification in the contemporary $\mathrm{AM} / \mathrm{PM}$ data, which migrates from the conventional radiographs to more technological imaging modalities. The human identification process benefits from this modification achieving more realistic and reliable comparison of forensic 

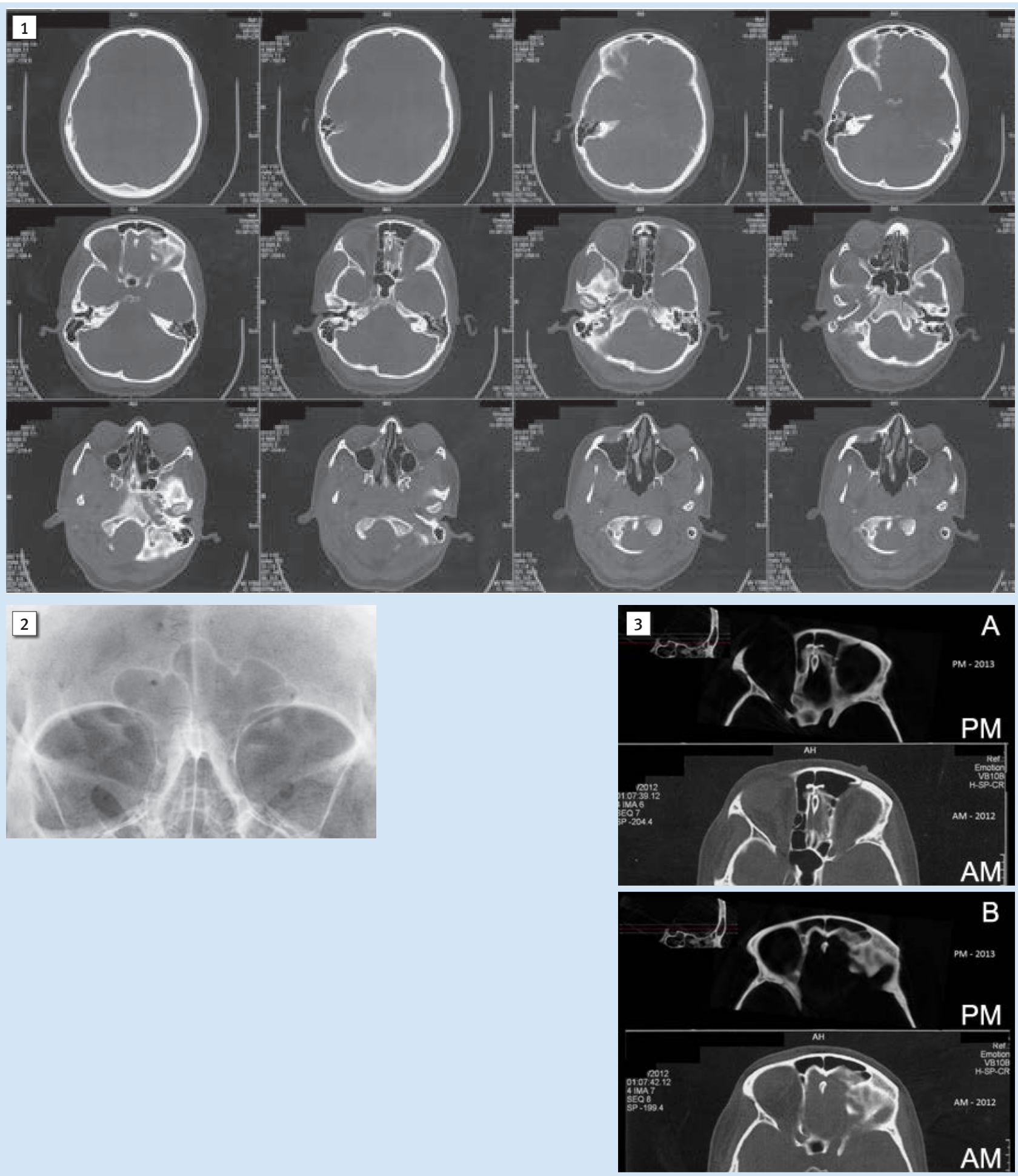

Slika 1. Aksijalni pogled prijesmrtnih MSCT slika - datirano 2012.

Figure 1 Axial view of the computed tomography images obtained ante-mortem, dating from 2012

Slika 2. Radiološka morfologija frontalnih sinusa dobivena poslijesmrtno vidljiva u posteroanteriornom radiogramu lubanje - datirano 2013.

Figure 2 Radiographic morphology of the frontal sinuses observed in the postmortem posteroanterior radiograph of the skull, dating from 2013

Slika 3. Usporedba prijesmrtnih (AM) i poslijesmrtnih (PM) slika s prikazom donjih (A), srednjih (B) i gornjih (C) regija frontalnih sinusa

Figure 3 Comparison between ante-mortem (AM) and post-mortem (PM) images showing the inferior (A), intermediate (B) and superior (C) regions of the frontal sinuses

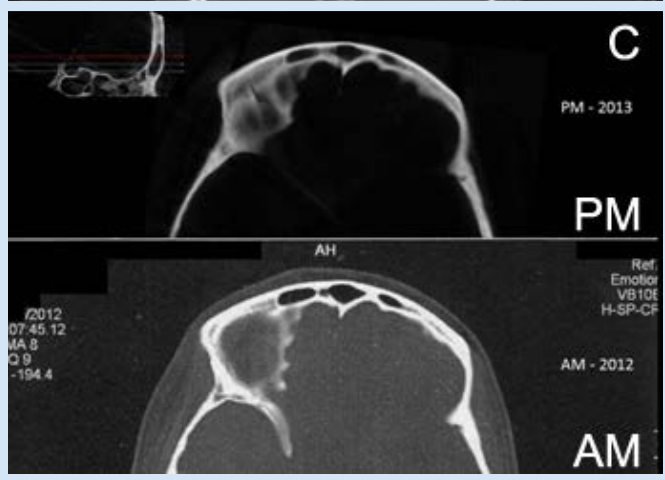


9). Korištenje slika visoke tehnološke razine važno je u složenim slučajevima raspadnutih/oštećenih tijela i tjelesnih ostataka kojima često nedostaju meka tkiva i otisci prstiju $(5,10)$. Znanstvena literatura podupire radiografsku analizu frontalnih sinusa u svrhu identifikacije na temelju karakterističnih morfoloških obilježja (11) te niske prevalencije njihove ageneze (12). Tradicionalno se frontalni sinusi procjenjuju s pomoću anteroposteriornih radiograma lubanje $(11,13)$, te se na njima obavljaju analize vertikalne i horizontalne dimenzije. Analiza anteroposteriornih dimenzija nije moguća zbog dvodimenzijskog prikaza (2D) tehnike $(11,13)$. Unatoč to$\mathrm{mu}$ što u ovom slučaju potpuni DICOM podatci CT pretrage nisu bili na raspolaganju, oni bi mogli omogućiti volumetrijsku (3D) dimenzijsku analizu $(14,15)$ te poboljšati interpretacijske dokaze u svrhu pozitivne identifikacije. Osim trodimenzijske analize (3D), važno je istaknuti i noviju literaturu u kojoj se istražuje potencijalno korištenje snimljenih radiograma (2D) paranazalnih sinusa (16). Tako su, na primjer, mjereni maksilarni sinusi radi razlikovanja spolova, kao korist pri rekonstruktivnoj identifikaciji u forenzičkoj antropologiji (16). Štoviše, takve procjene biološkog profila žrtava prijeko su potrebne zbog mogućeg sužavanja popisa nestalih osoba, posebno u složenim slučajevima poput nesreća s višestrukim smrtima.

Dodatno područje relevantnosti prikazanog slučaja jest usporedivanje prijesmrtnih MSCT slika s poslijesmrtnim CBCT-om. Iako se MSCT uređaji uobičajeno koriste u medicinske svrhe, još nisu postali standardni sastavni dio ovlaštenih medicinsko-patoloških ustanova diljem svijeta. U opisanom slučaju CBCT se pokazao kao alternativa za dobivanje sličnih poslijesmrtnih slika za analizu i usporedbu s dobivenim aksijalnim prijesmrtnim slikama. Do ovog prikaza slučaja u literaturi nema izvještaja u kojem je provedena uspješna identifikacija ljudskih ostataka isključivo na temelju morfoloških forenzičkih dokaza dobivenih na CT aksijalnim slikama frontalnih sinusa.

\section{Zaključak}

Opisani slučaj pokazuje koliko je važno pravilno čuvati medicinske nalaze i koliko su nužni u pravosuđu. Dodatno, prikazana je važnost interpretacije CT prikaza frontalnih sinusa u slučaju kada su oni jedini izvor za forenzičke dokaze.

\section{Sukob interesa}

Autori nisu bili u sukobu interesa. data $(3,9)$. The use of high-tech imaging techniques plays a valuable role in complex cases involving decomposed/charred bodies and skeletal remains, from which soft tissues and fingerprints are frequently damaged $(5,10)$.

The scientific literature supports the findings of the radiographic analysis of the frontal sinus for human identification purposes based on its distinctive morphological pattern (11) and low prevalence rate for agenesis (12). Traditionally, the frontal sinus is assessed with posteroanterior radiographs of the skull $(11,13)$ in which the analysis of vertical and horizontal dimensions is performed. The analysis of anteroposterior dimensions remains unfeasible due to the inherent bidimensional (2D) aspect of the technique (11, 13). Although they were not available in the present case, complete DICOM files from CT scans of the frontal sinuses could enable the analysis of volumetric (3D) dimensions $(14,15)$ and improve the interpretation of findings to support a positive identification. Apart from the three-dimensional (3D) analysis, it is important to highlight the recent literature that explores the potential use of the paranasal sinuses registered radiographically (2D) for human identification (16). For example, the maxillary sinuses can be measured for sex discrimination to aid reconstructive identifications via forensic anthropology (16). Moreover, these pathways for assessing the biological profile of the victims are essential especially in more complex situations, such as incidents involving multiple deaths, due to their potential for narrowing the lists of missing persons.

Another topic of relevance in the present case was the comparison between AM MSCT images and PM CBCT images. Despite being found in some medical services, MSCT units have not become commonly used in a large number of medico-legal facilities worldwide. In the present study, Cone Beam Computed Tomography (CBCT) was the available alternative to enable a similar image analysis and to properly reproduce PM axial images obtained from AM images. So far, there have been no studies in the literature which have reported a case of human identification based exclusively on morphological forensic evidence observed in CT axial images of the frontal sinuses.

\section{Conclusion}

The present case report points out that it is very important that the images are stored properly in order to be clinically useful. Also, it highlights the fact that such images need to be provided for court procedures. Additionally, it encourages the training on the interpretation of CT images of the frontal sinus to support cases in which they are the only available forensic evidence.

\section{Conflict of interest}

None declared 
Abstract

Objective: The aim of this paper is to report on a case of positive human identification of a decom posed body after the comparison of ante-mortem (AM) and port-mortem (PM) computed tomography images of frontal sinus. Case report: An unknown, highly decomposed human body, aged between 30 and 40 years, was found in a forest region in Brazil. The dental autopsy revealed several teeth missing AM and the presence of removable partial prostheses. The search for AM data resulted in a sequence of 20 axial images of the paranasal sinuses obtained by Multislice Computed Tomography (MSCT). PM reproduction of the MSCT images was performed in order to enable a comparative identification. After a direct confrontation between AM/PM MSCT, the data were collected for morphological findings, specifically for the lateral expansion of the left lobe, the anteroposterior dimension, and the position of median and accessory septa of the sinuses. Conclusion: The importance of storing and interpreting radiographic medical data properly is highlighted in this text, thus pointing out the importance of application of forensic radiology in the field of law.
Received: December 1, 2016

Accepted: February 13, 2017

Address for correspondence Rhonan Ferreira Silva

Forensic Dentistry

Federal University of Goias

Av. Universitaria, Esquina com $1^{\text {a }}$

Avenida $\mathrm{s} / \mathrm{n}$,

Setor Universitario

Postal code: $74605-220$

Goiania, Goias, Brazil

Phone: 00556232096051

rhonanfs@terra.com.br

Key words

Forensic Anthropology; Human Identification; Frontal Sinus; X-Ray Computed Tomography; Forensic Dentistry; Denture Identification Marking

\section{References}

1. Thali, MJ; Viner, MD; Brogdon, BG - editors. Brogdon's forensic radiology. 2nd ed. Boca Raton: CRC Press; 2010.

2. Matoso RI, Benedicto Ede N, de Lima SH, Prado FB, Daruge E, Da ruge Júnior E. Positive identification of a burned body using na implanted orthopedic plate. Forensic Sci Int. 2013 Jun 10;229(1. 3):168.e1-5.

3. Franco A, Thevissen P, Coudyzer W, Develter W, Van de Voorde W, Oyen R, et al. Feasibility and validation of virtual autopsy for dental identification using the Interpol dental codes. J Forensic Leg Med. 2013 May;20(4):248-54.

4. Wood RE. Forensic aspects of maxillofacial radiology. Forensic Sci Int. 2006 May 15;159 Suppl 1:S47-55.

5. Silva RF, Botelho TL, Prado FB, Kawagushi JT, Daruge Júnior E, Bérzin F. Human identification based on cranial computed tomography scan - a case report. Dentomaxillofac Radiol. 2011 May;40(4):257-61.

6. McKern, TW; Stewart, TD - editors. Skeletal age changes in young American males. Natick: Quartermaster Research \& Development Command; 1957.

7. Watanabe S, Terazawa K. Age estimation from the degree of osteophyte formation of vertebral columns in Japanese. Leg Med (Tokyo). 2006 May;8(3):156-60

8. Trotter M, Gleser GC. Estimation of stature from long bones of American whites and negroes. Am J Phys Anthropol. 1952 Dec;10(4):463-514

9. Sakuma A, Saitoh H, Makino Y, Inokuchi G, Hayakawa M, Yajima $\mathrm{D}$, et al. Three-dimensional visualization of composite fillings for dental identification using CT images. Dentomaxillofac Radiol. 2012 Sep;41(6):515-9.

10. Silva RF, Franco A, Mendes SD, Picoli FF, de Azevedo Marinho DE. Human identification through the patella - report of two cases. Forensic Sci Int. 2014 May;238:e11-4.

11. Patil N, Narjodkar FR, Sontakke SS, Sansare K, Salvi R. Uniqueness of radiographic patterns of the frontal sinus for personal identification. Imaging Sci Dent. 2012 Dec;42(4):213-7.

12. Gotlib T, Kuzminska M, Held-Ziolkowska M, Osuch-Wojcikiewicz E, Niemczyk K. Hidden unilateral aplasia of the frontal sinus: a radioanatomic study. Int Forum Allergy Rhinol. 2015 May;5(5):441 4.

13. Silva RF, Franco A, Dias PEM, Gonçalves AS, Paranhos LR. Interrelationship between forensic radiology and forensic odontology - a case report of identified skeletal remains. J Forensic Radiol Imag. 2013;1(4):201-6

14. Kim DI, Lee UY, Park SO, Kwak DS, Han SH. Identification using frontal sinus by three-dimensional reconstruction from computed tomography. J Forensic Sci. 2013 Jan;58(1):5-12.

15. Beaini TL, Duailibi-Neto EF, Chilvarquer I, Melani RF. Human identification through frontal sinus 3D superimposition: pilot study with cone-beam computed tomography. J Forensic Leg Med. 2015 Nov;36:63-9.

16. Queiroz CL, Terada ASSD, Dezem TU, Araújo LG, Galo R, Oliveira-Santos $C$, et al. Sex dsicrimination of adult human maxillary sinuses on paranomic radiographs. Acta Stomatol Croat. 2016 Sep;50(3):215-221. 